\title{
Value added in sawmilling industry in the Czech Republic
}

\author{
Petra Palátová \\ Czech University of Life Sciences Prague, Faculty of Forestry and Wood Sciences, Kamýcká 129, CZ - 16500 Praha 6-Suchdol, \\ Czech Republic
}

\begin{abstract}
The paper deals with sawmilling and timber processing capacities in the territory of the Czech Republic. Selected operations are sawmills with the annual processing capacity over $10,000 \mathrm{~m}^{3}$, further divided into groups by the annual volume of processed raw material. In total 35 companies, which were chosen at random, were compared based on the indicator of value added per employee. The results show that the value added considerably differed not only among the groups but also within the individual groups of sawmill establishments.
\end{abstract}

Key words: primary timber processing; sawmills; capacity; economic indicators

\section{Introduction}

Primary timber processing is one of long-tradition industries in the Czech Republic with the advantage of continually increasing stock in forest stands (Report on the state of forests and forestry 2016) and sufficient processing capacities. On the other hand, the timber processing industry in the Czech Republic (and similarly in Slovakia) shows certain problems such as "low finalization of production, high exports of low value added products, and hence the low creation of value added in the sector (Sujová et al. 2015)". At that, the increasing level of timber processing is one of strategic goals of the European Union (Sujová et al. 2017). In this context, it is important to use at full all available sawmilling capacities as well as their installed output whose increase in value may be the indicator of value added.

Kovalčík (2011) used indicators of gross and net value added to compare forestry sectors in various countries. Of other professional studies focused specifically on timber processing, worth mentioning is for example a publication evaluating wood processing companies in the Czech Republic, Slovakia and Austria (Sujová et al. 2015). Timber industry is also a subject of study published by Kupčák and Šmída (2015), who focused their attention on the largest sawmill operations with foreign owners in the Czech Republic.

The aim of the paper is to verify whether large sawmill operations achieve value added higher than smaller sawmills. For this purpose, the indicator of value added per employee was used, which makes it possible to compare the individual operations. In order to meet the goal, data on the selected companies had to be updated, i.e. existence, financial results and numbers of employees.

\section{Material and methods}

Data used in the paper were obtained through the secondary research of scientific literature, public registries - Companies Register (value added and number of employees for particular companies in their annual year reports), reports issued by the Ministry of Industry and Trade-so-called Panoramas of manufacturing industries (value added and number of employees for sub-division CZ NACE 16.1), Register of Insolvencies, Trades Register (both to verify whether the company is still active) and Reports on the State of Forests and Forestry. Above mentioned registers are available at web pages isir.justice.cz and or.justice.cz.

Default indicators applied in the paper include manufacturing capacity, value added and calculated value added per employee.

The paper further uses recalculated average values (based on simple arithmetic mean) according to the formula : $\frac{1}{n} \sum_{i=1}^{n} x_{\mathrm{i}}$

Because the arithmetic mean is sensitive to extreme values, which occur within the studied set, the more accurate median was also used. Variation range (R) informs about the variability of the studied sample. It is calculated as a difference between the maximum and the 
minimum values of the selected variable; $R=x_{\max }-x_{\min }$. In this paper, the variation range points to differences of results reported by companies falling into the same categories (categorization of sawmilling operations see below). For better clarity, the recalculated values are rounded up to entire units.

Value added can be defined as a "difference between the enterprise outputs and its consumption for the outputs. Outputs are revenues from the sales of own products and services, activation and change in the inventory of own activities, consumption for the outputs consisting of the consumption of materials, energies and services (Pejzl \& Slonek 2006)". Value added in sawmill production is affected by a number of factors of internal and external character. Internal factors can be considered for example the volume of production, volume of own products sold, sale price setting, manufacturing capacity, associated costs etc. External factors reflect namely the development of input raw material price, access to the sufficient amount of raw material in demanded quantity and quality, development of demand, sector recession or boom (Pejzl \& Slonek 2006). In absolute expression, the indicator of value added cannot grasp differences among the facilities, and this is why a relative variant of this indicator is used - value added per 1 employee.

For the purposes of this paper, the author selected sawmill operations with the processing capacity over $10,000 \mathrm{~m}^{3}$, i.e. medium-size sawmills, bigger mediumsize sawmills, big sawmills and large-scale sawmills. Below, the categories of sawmill operations are listed by their annual processing capacities according to Detvaj (2003):

- Processing capacity up to $2,499 \mathrm{~m}^{3}$ (very small sawmills),

- Processing capacity from 2,500 - 4,999 $\mathrm{m}^{3}$ (small sawmills),

- Processing capacity from 5,000 - 9,999 m³ (smallersize sawmills),

- Processing capacity from 10,000 - 19,999 $\mathrm{m}^{3}$ (medium-size sawmills),

- Processing capacity from 20,000 - 49,999 m³ (bigger medium-size sawmills),

- Processing capacity from 50,000 - 200,000 m³ (big sawmills),

- Processing capacity over 200,000 $\mathrm{m}^{3}$ (large-scale sawmills).

Sawmills with the annual processing capacity up to $10,000 \mathrm{~m}^{3}$ are not considered due to the limited extent of the paper. Individual sawmilling facilities were chosen for the assessment from the list of operations according to Pražan (2010). Subsequently, the establishments were divided into groups according to the respective categories by their processing capacity. In the studied period (see Pražan 2010; Pecháček 2016), the category of largescale sawmills included 5 corporations residing in the Czech territory. At present, there is another facility that could have been included in the category of large-scale sawmills with the processing capacity over $200000 \mathrm{~m}^{3}$
- LESS \& TIMBER in Č́slav. At first, because there are five representatives in the category of large-scale sawmills, five representatives were chosen for all other categories, too. Then, there were included other companies, in order to describe the situation in each category in more detail. Because there is no official database of domestic sawmilling companies, they were chosen again at random from the list of companies according to Pražan (2010), in categories bigger sawmills and medium sawmills to represent around 1/4 of companies mentioned in respective categories, which in total means 34 companies in this article. Data on the companies were surveyed in June 2017.

Although companies in general have the duty to publish their data annually, it was not possible to find data for 2016 for all selected companies and the results would not be comparable. Because of that, 2015 was chosen as the reference year.

\section{Results}

\subsection{Sawmill production and wood impregnation}

According to the Classification of economic activities in the Czech Republic, primary timber processing is included in Section C-manufacturing industry, Division CZ NACE 16. In the sub-division CZ NACE 16.1, we find sawmill production and wood impregnation. The subdivision CZ NACE 16.2 includes manufacture of wood, cork, wicker and straw products with the exception of furniture (CZ NACE 2017). In terms of value added, the sub-division CZ NACE 16.1 contributes only with 20.8\% to the value added generated within Division CZ NACE 16 (Panorama of the manufacturing industry 2016).

The level of value added in the sub-division 16.1 does not exhibit larger changes between the years. Although the value added per employee is increasing according to data, it should be pointed out that the number of employees between the years is decreasing. Selected information about division CZ NACE 16 and sub-division 16.1 are presented in Table 1.

\subsection{Sawmill operations}

As to the requirements for primary wood processing, sawmills are represented sufficiently in the Czech Republic, relatively regularly located across the country. Nevertheless, there are distinct differences among them - for example in their processing capacities (maximal in dependence on available technology and actually implemented capacity), structure of assortments, different standard of mechanization and automation, number of employees, customer networks, etc. The capacity of processing itself is then a good criterion in the classification of these facilities, its volume being affected by 
Table 1. Indicators selected for Division CZ NACE 16 and sub-division CZ NACE 16.1.

\begin{tabular}{|c|c|c|c|c|c|c|}
\hline Year & 2011 & 2012 & 2013 & 2014 & 2015 & 2016 \\
\hline \multicolumn{7}{|c|}{ CZ NACE 16} \\
\hline Value added (VA) in CZK & 20848068 & 20205569 & 20702359 & 22044295 & 23143349 & 24782688 \\
\hline Number of units & 29495 & 29405 & 27849 & 27553 & 27672 & 27640 \\
\hline VA/employee in CZK & 594686 & 586131 & 643256 & 714352 & 741270 & 818392 \\
\hline \multicolumn{7}{|c|}{ CZ NACE 16.1} \\
\hline Value added (VA) in CZK & 3910139 & 3347464 & 4042997 & 4599906 & 4411053 & 5143072 \\
\hline Number of units & 2240 & 2071 & 1901 & 1765 & 1691 & 1585 \\
\hline VA/employee in CZK & 515787 & 461255 & 605034 & 715588 & 691350 & 809676 \\
\hline
\end{tabular}

Source: Ministry of Industry and Trade, 2018.

a number of factors mentioned by Pražan (2010). With respect to the missing information sources about the current processing capacities implemented by the respective companies, the division of operations dwells on the situation in 2009 according to Pražan (2010).

The following data on sawmill operations are ordered by their size according to individual categories:

\subsection{Large-scale sawmills}

The category of large-scale sawmills includes sawmilling operations with the annual processing capacity over $200,000 \mathrm{~m}^{3}$ (Detvaj 2003). In addition to sawmills with foreign property participation (Mayr-Melnhof Holz Paskov (hereinafter M-M Paskov), Stora Enso Wood Products Ždírec (hereinafter SE Ždírec) and Stora Enso Wood Products Planá (hereinafter SE Planá), the category also includes Dřevozpracující družstvo (Wood Processing Cooperative) Lukavec (DD Lukavec) and the Javoriice Sawmill. Tables 2 and 3 present the company names without their legal status (DD Lukavec is a cooperative, Javořice is a joint-stock company and the other three are limited liability companies (ARES 2018).

Table 2. Value added (thousand CZK) in selected sawmill operations - large-scale sawmills.

\begin{tabular}{lcccccc}
\hline Sawmill/Year & 2011 & 2012 & 2013 & 2014 & 2015 & 2016 \\
\hline DD Lukavec & 254757 & 247779 & 274459 & 361542 & 331101 & N/A \\
Javořice & 6066 & 11030 & 48461 & 98835 & N/A & N/A \\
SE Ždírec & 382809 & 360029 & 567876 & 649520 & 596127 & N/A \\
SE Planá & 316129 & 258693 & 360177 & 487514 & 436833 & 385727 \\
M-M Paskov & 393258 & 262036 & 561008 & 684934 & 546203 & 741517 \\
On average & 270604 & 227913 & 362396 & 456469 & - & - \\
\hline Source: Companies Register - annual reports of the individual companies; 2011-2017 (“Sbir- \\
ka listin”).
\end{tabular}

Table 3. Value added converted to 1 employee in selected sawmill operations - large-scale sawmills (in CZK).

\begin{tabular}{lcccccc}
\hline Sawmill/Year & 2011 & 2012 & 2013 & 2014 & 2015 & 2016 \\
\hline DD Lukavec & 429607 & 425737 & 478152 & 635399 & 581900 & N/A \\
Javořice & 159632 & 169692 & 452907 & 923692 & N/A & N/A \\
SE Ždírec & 1020824 & 949945 & 1200584 & 1402851 & 1245662 & N/A \\
SE Planá & 1311739 & 1119883 & 1622419 & 2267507 & 2003821 & 1662616 \\
M-M Paskov & 1618346 & 1056597 & 2235092 & 2604312 & 2008099 & 2657767 \\
\hline Source: Companies Register - annual reports of individual companies; 2011-2017 (“Sbírka \\
listin”), own compilation.
\end{tabular}
listin"), own compilation.
The calculated average value in Table 2 is only a very orientation criterion because it does not take into account possible distinctive deviations between the extreme values - maximum and minimum, in this case the extremely different result in the Javořice Sawmill. The low level of value added in 2011 as well as in the following years was in this sawmill a likely consequence of insolvency in 2010 and the following reconstruction of the establishment. The highest values in absolute expression as well as the highest value per employee were reported by Mayr- Melnhof Holz Paskov, Ltd., in 2016.

\subsection{Big sawmills}

Representatives of big sawmills (i.e. with the processing capacity from $50,000-200,000 \mathrm{~m}^{3}$ /year) were the following companies: Jihoobal Dlouhé pole, Holz Schiller, Dřevopar (in all cases a limited liability company “LLC”), Pila Tetčice (Tetčice Sawmill), Klaus Timber (both with legal status of joint-stock company, further used abbreviation "JSC"). Information about big sawmills are presented in Table 4.

Table 4. Value added (in CZK) in selected sawmill operations for 2015 (big sawmills).

\begin{tabular}{lcccc}
\hline \multicolumn{1}{c}{ Sawmill } & Legal status & $\begin{array}{c}\text { Value added } \\
\text { (VA) }\end{array}$ & $\begin{array}{c}\text { Number } \\
\text { of employees }\end{array}$ & VA/employee \\
\hline Jihoobal & LLC & 11419036 & 34 & 335854 \\
Holz Schiller & LLC & 197989000 & 406 & 487658 \\
Dřevopar & LLC & 8624000 & 64 & 134750 \\
Pila Tetčice & JSC & 23323000 & 64 & 364422 \\
Klaus Timber & JSC & 148405000 & 240 & 618354 \\
\hline Mean & - & 77952007 & 162 & Variation range \\
Median & - & 23323000 & 64 & $=483604$ \\
\hline
\end{tabular}

Source: Companies Register - annual reports of individual companies; 2017, (“Sbírka listin”), own compilation.

The number of employees in the companies in this category confirms that the division of sawmill operations by the number of employees would not illustrate reality as to the establishment size. The lowest and the highest numbers of employees were 34 and 406 persons, respectively. The level of value added per employee greatly differed as well - the lowest being 134,750 CZK and the highest being $618,354 \mathrm{CZK}$. The variation range was 483,604 CZK.

\footnotetext{
${ }^{1}$ The value of the indicator is not accessible.
} 


\subsection{Bigger medium-size sawmills}

In this category (annual breakdown capacity from 20,000 $-50000 \mathrm{~m}^{3}$ ) there were representative companies see Table 5.

Rising above all the other companies in this category is Matrix, with the highest number of employees and the highest value added per employee at the same time $(883,742 \mathrm{CZK})$. Variation range in the level of value added per employee is higher than in the above category - reaching 606,833 CZK.

Table 5. Value added (in CZK) in selected sawmill operations for 2015 (bigger medium-size sawmills).

\begin{tabular}{lcccc}
\hline \multicolumn{1}{c}{ Sawmill } & Legal status & Value added & $\begin{array}{c}\text { Number } \\
\text { of employees }\end{array}$ & VA/employee \\
\hline Cedro & LLC & 6092000 & 22 & 276909 \\
Pila Černý & LLC & 18138000 & 43 & 421814 \\
Pila Sedlo Servis & LLC & 7822000 & 13 & 601692 \\
Kaiser & LLC & 41179000 & 89 & 462685 \\
Matrix & JSC & 134329000 & 152 & 883743 \\
Carman-Wood & LLC & 12146000 & 34 & 357235 \\
Timber Production & LLC & 18887000 & 54 & 349759 \\
Empo Holz & LLC & 30978000 & 50 & 619560 \\
Dřevozávod Pražan & LLC & 21136000 & 63 & 335492 \\
\hline Mean & - & 32301000 & 58 & Variation \\
Median & - & 18887000 & 50 & range $=606833$ \\
\hline
\end{tabular}

Source: Companies Register - annual reports of individual companies; 2017, (“Sbírka listin”), own compilation.

\subsection{Medium-size sawmills}

Representatives chosen for annual breakdown capacity from $10,000-20,000 \mathrm{~m}^{3}$ are 15 companies, mentioned in Table 6.

Table 6. Value added (in CZK) in selected sawmill operations for 2015 (medium-size sawmills).

\begin{tabular}{lcccc}
\hline \multicolumn{1}{c}{ Sawmill } & Legal status & Value added & $\begin{array}{c}\text { Number of } \\
\text { employees }\end{array}$ & VA/employee \\
\hline Pila Benda & LLC & 10082000 & 19 & 530632 \\
Pila Otaslavice & LLC & 2302000 & 10 & 230200 \\
Pila Hrachovec & LLC & 4458954 & 15 & 297264 \\
Optima Lanškroun & LLC & 4384000 & 14 & 313143 \\
Level O2 & JSC & 6463000 & 30 & 215433 \\
Skapo & LLC & 3310000 & 14 & 236429 \\
Pila Füllsack & LLC & 10615000 & 36 & 294861 \\
Pila Krnov & LLC & 5121000 & 22 & 232772 \\
Gatro & LLC & 6407000 & 26 & 246423 \\
Pila Zámrsk & LLC & 3859000 & 15 & 257267 \\
Pila Facek & LLC & 10091000 & 31 & 325516 \\
Pila Karel Vlček & LLC & 20440000 & 45 & 454222 \\
B. Turner & LLC & 4763000 & 11 & 433000 \\
Benko, dřevařský & LLC & 15523000 & 74 & 209770 \\
podnik, Kopidlno & LLC & 19199000 & 54 & 355537 \\
Nema & - & 8467864 & 28 & Variation \\
\hline Mean & - & 6407000 & 19 & range=320 862 \\
Median & -
\end{tabular}

Source: Companies Register - annual report of individual companies; 2017, (“Sbírka listin”), own compilation.

These establishments feature the least differences in the number of employees. Value added per employee does not differ too much either, which is documented by the lowest value of variation range within all the categories of sawmill operations $(320,862 \mathrm{CZK})$.
The following Table 7 presents an information sum mary.

Table 7. Summary table (large-scale sawmill operations excluded).

\begin{tabular}{lcccc}
\hline $\begin{array}{c}\text { Sawmill } \\
\text { operation } \\
\text { category }\end{array}$ & $\begin{array}{c}\text { Number } \\
\text { of } \\
\text { employees }\end{array}$ & $\begin{array}{c}\text { Value added per 1 } \\
\text { employee in CZK }\end{array}$ & $\begin{array}{c}\text { Value added } \\
\text { - mean value } \\
\text { in CZK }\end{array}$ & $\begin{array}{c}\text { Average } \\
\text { number } \\
\text { of employees } \\
\text { (mean value) }\end{array}$ \\
\hline Big & $34 / 406$ & $134750 / 618354$ & 77952007 & 162 \\
Bigger-medium & $13 / 152$ & $276909 / 883742$ & 31403000 & 58 \\
Medium & $10 / 74$ & $209770 / 530632$ & 8467864 & 28 \\
\hline Source: own compilation based on data from previous tables.
\end{tabular}

\section{Discussion}

The sector of primary timber processing has a long tradition in the Czech Republic and its current advantage is the sufficient base of raw material. However, sawmills are focused on making low-value-added products such as sawn timber, whose considerable volume is exported to neighbouring countries. Moreover, the exports show increasing trends (see for example Report on the State of Forests and Forestry 2013, 2016) and the issue of low products finalizations has been discussed for several years already. The National Forestry Programme (2008) informs that more than a half of extracted timber is exported as raw or half-finished material to foreign countries. In 2012, the Czech Republic even became the largest exporter of raw timber in the European Union (Šafaŕík 2013). Raw timber exports seem illogical also because various studies indicate that the country has sufficient processing capacities (see for example Pecháček 2016; APICON 2016); this means in other words that raw material, which is exported now, could be effectively manufactured in the home country.

In spite of this, the Ministry of Industry and Trade (Panoramas of Manufacturing Industries 2013, 2014, 2016) has been pointing out an opposite problem in its reports -i.e. lack of manufacturing capacities for several years. According to information from 2014, the lack of manufacturing capacities is the main reason why lowvalue-added products are primarily offered on the market (Panorama of the manufacturing industry, 2014). Adeclaration from 2016 contains a formulation about the plan to establish a forest and forest products industries fund, which would support the emergence of new sawmills and other timber processing operations in line with the increasing demand for raw wood (namely in terms of marketing) (Panorama of Manufacturing Industry, 2016). However, such a fund does not exist so far.

Another interesting fact is that although the discussions about the size and capacity of sawmill operations have been permanently continued, the statements published by Pražan (2017) still hold true: "there is in fact no official or commonly used calculation to determine the capacity of an establishment, most manufacturers of saw- 
mill technologies indicating the maximumoutput of breakdown lines. Most plausible is the historically achieved amount of processed raw material reported by individual companies". The achieved level of breakdown is a base for data in this paper, too; nevertheless, obtainment of current data from the companies is somewhat problematic.

Factors influencing the sawing capacity were discussed, for example, in paper by Bomba et al. (2016), depending primarily on the number of employees, the primary technology, level of mechanisation etc. Technical efficiency in production in sawmilling industry was discussed by Šedivka (2009).

Cardinal role in determining actual and potential processing capacity plays the availability of raw material at a required amount and quality. Since the establishments are often located near populated areas, there are also some restrictions concerning manufacturing processes (noise, illumination) that may reflect into working on shifts at night or in early morning hours (Pražan 2017).

Other limitations for sawmilling facilities follow out from the setting of customer-supplier relations and reflect both in the manufacturing process and in the costs. This concerns for example supplies of certified raw material and products through PEFC and FSC systems when the companies choose a particular certification scheme with respect to requirements on the part of prominent customers. The certification of so-called consumer chains is dealt with for example by Dudík \& Riedl (2015), Paluš et al. (2017, 2018).

Matrix, the company which achieved the highest value added in its category (as well as the highest value added per employee), deals in its manufacturing programme also with the reputable assortments of oak and larch sawn timber whose conversion into money is high. Thus, the level of value added is possibly affected by these factors in addition to the wide range of business activities.

The company Dřevopar exhibited the lowest value added per employee of all studied operations. In the last years of 2015 and 2016, the level of value added was lower than corresponding to the previous development. This shows that even the indicator of value added might have suggested the company's upcoming problems. Since the end of year 2017, the company has been in insolvency and current information (March 2018) signals that the company is standing before the decision on bankruptcy. With respect to the studied period (i.e. data being assessed in June 2017), the company remained in the list.

\section{Conclusion}

The paper is focused on selected sawmill operations, which were divided into categories by their processing capacity. Considered were companies with the annual breakdown capacity larger than $10000 \mathrm{~m}^{3}$ and there were 34 establishments surveyed in total.
As a criterion for comparison, the author selected the indicator of value added per employee. The initial assumption about a markedly higher indicator of value added in large-scale sawmills was obvious in enterprises with the foreign participation; otherwise considerable variations were observed both among the groups of facilities and within the respective groups.

Holz Schiller provides the highest number of jobs (406 persons) while Pila (Sawmill) Otaslavice provides the lowest number of jobs (10 persons). The lowest indicator of value added was recorded in the company Dřevopar (134,750 CZK per employee) and the highest one in Mayr-Melnhof Holz Paskov (2,657,767 CZK per employee). The variation range of the indicator of value added per employee was the highest in the large-scale sawmills, the results being considerably affected by those of Pila (Sawmill) Javorrice. In the studied year of 2015, bigger medium-size sawmills exhibited the highest variation range $(606,833 \mathrm{CZK})$ and the lowest variation range was recorded in the last surveyed category-medium-size sawmills $(320,862 \mathrm{CZK})$.

Except year 2014, there is always a higher value added per employee on average in CZ NACE 16 than in CZ NACE 16.1. All categories, except the only company - Matrix - do not reach the value added per employee higher than is the average of CZ NACE 16.1 in 2015. Large-scale sawmills, namely S-E Ždírec, S-E Planá and M-M Paskov reach at least double values of this indicator.

The indicator of value added encompasses all profitmaking activities of companies. However, value added for sawmill production cannot be singled out from publicly available statistics. Value added is affected by range of business activities, size of the company, technical equipment, availability and type of processed raw material, etc. The fact remains that methods should be sought for how to increase value added in the primary sector of wood processing. One of them is promotion of wood product to the wider public.

Because the demand for wood is a driven demand depending on the situation in other industries, that use wood as a raw material (like pulp and paper industry, furniture making industry etc.), the development of value added in the wood-processing industry might be affected also by situation in these industries. The research could further deal with the comparison of value added in sawmilling in countries with similar conditions to those in the Czech Republic, like Austria and Germany. Price determination in the Czech Republic is also correlated with the price development in the above mentioned countries.

\section{Acknowledgements}

The author is grateful for the grant supported by the National Agency for Agricultural Research of the Ministry of Agriculture of the Czech Republic (project No. QJ1530032). 


\section{References}

Bomba, J., Böhm, M., Šedivka, P., Friess, F., Orálková, R., 2016: Influence of selected factors on the sawing capacity of sawmills in the Czech Republic. Scientia Agriculturae Bohemica, 47:174-180.

Detvaj J., 2003: Technologia piliarskej výroby. Vysokoškolská učebnica, Zvolen, TU, 131 p.

Dudík, R., Riedl, M., 2015: The possibilities of using C-O-C certifications in the Czech Republic. In: Jelačić (eds.): Wood Processing and Furniture Manufacturing Challenges on the World Market and WoodBased Energy Goes Global - Proceedings of Scientific Papers. WoodEMA, p. 229-233.

Kovalčík, M., 2011: Profitability and competitiveness of forestry in European countries. Journal of Forest Science, 57:369-376.

Kupčák, V., Šmída, Z., 2015: Forestry and wood sector and profitability development in the wood-processing industry of the Czech Republic. Journal of Forest Science, 61:244-249.

Paluš, H., Parobek, J., Dudík, R., Šupín, M., 2017: Assessment of chain-of-custody certification in the Czech and Slovak Republic. Sustainability, 9:1-13.

Paluš, H., Parobek, J., Vlosky, R. P. et al., 2018: The status of chain-of-custody certification in the countries of Central and South Europe. European Journal of Wood and Wood Products, 76:699-710.

Pecháček, O., 2016: Aktualizace zjištění potenciálu dřevozpracujících podniků. Lesnická práce, 95:3133.

Pejzl, J., Slonek, L., 2006: Pilařské provozy z pohledu přidané hodnoty výroby. Lesnická práce, 85:24.

Pražan, P., 2010:Analýza faktorů možnostívývoje malých a středních pilařských provozů v ČR. Disertační práce. Praha, CZU, 129 p.

Pražan, P., 2017: Jaké jsou v České republice pilařské kapacity a kolik jich je potřeba? Lesnická práce, 96:44-45.

Sujová, A., Hlaváčková, P., Šafařík, D., 2015: Analýza výkonnosti drevospracujúceho priemyslu prostredníctvom pomerových ukazovatelov. Acta Facultatis Xylologiae Zvolen, 57:165-178.
Sujová, A., Michal, J., Kupčák, V., Dudík, R., 2017: The impact of international trade of raw wood to the economic growth of forest-based sectors in the Czech and Slovak Republics, BioResoures, 12:1102-1111.

Šafařík, D., 2013: Konkurenceschopnost a ekonomická životaschopnost dřevozpracujícího průmyslu v České republice. In: Polster, P. (eds.): Semináře Komise lesnické ekonomiky Odboru Lesního hospodářství ČAZV. Sborník referátů ze seminářů s mezinárodní účastí Plumlov, Strážné. Praha, ČZU, p. 21-28.

Šedivka, P., 2009: Estimation of Technical Efficiency in Production Technologies of Czech Sawmills. Drvna Industrija, 60:197-207.

\section{Other sources}

APICON, 2016: Analýza dopadů zvýšení objemu dříví zpracovávaného na území České republiky. In: Lesy České republiky, s. p. [online]. Available at: https:// lesycr.cz/wp-content/uploads/2016/12/zpracovatelsky-potencial-web.pdf

ARES, 2018: Přehled vybraných ekonomických subjektů. Administrativní registr ekonomických subjektů [online]. Praha, Ministerstvo financí. Available at: http://wwwinfo.mfcr.cz/ares/ares_es.html.cz

Ministerstvo spravedlnosti ČR, 2017: Companies register (Veřejný rejstř́k a Sbírka listin) [online]. Available at: https://or.justice.cz/ias/ui/rejstrik

Český statistický úřad, 2017: Klasifikace ekonomických činností (CZ-NACE). Available at: https://www. czso.cz/csu/czso/klasifikace_ekonomickych_cinnosti_cz_nace

National Forestry Programme. (Národní lesnický program pro období do roku 2013: hlavní zásady společné zemědělské politiky, tržní politiky a politiky rozvoje venkova). Brandýs nad Labem, Ústav pro hospodářskou úpravu lesů, 2008.

Ministry of Industry and Trade, 2006: Panorama of the Manufacturing Industry of The Czech Republic. Praha, Ministerstvo průmyslu a obchodu.

Ministry of Agriculture, 2017: Report on the state of forests and forestry in the Czech Republic. Praha, Ministerstvo zemědělství ČR, 132 p. 